\title{
A case of gluten sensitive enteropathy, who presented with difficulty in walking
}

\author{
Yürüme güçlüğ̈̈ ile belirti veren gluten enteropatili bir olgu \\ Sevil Ceyhan Doğan*, Emel Güler, Emrullah Hayta, Sami Hizmetli, Sefa Aktı
}

Department of Physical Medicine and Rehabilitation (Assist. Prof. S. Ceyhan Doğan, MD, Assist. Prof. E. Hayta, MD, Prof. S. Hizmetli, MD), Cumhuriyet University School of Medicine, TR58140 Sivas, Department Of Physical Medicine And Rehabilitation (E. Güler, MD), Kayseri Education And Research Hospital, TR-38010 Kayseri, Departments of Orthopaedics and Traumatology (S. Akt1, MD), Sivas Numune Hospital, TR-58040

\begin{abstract}
Osteomalacia is a metabolic bone disease, which occurs due to impaired bone mineralization resulted from insufficient activity of vitamin D. Main reasons for vitamin D deficiency include malabsorptive states, diet with poor vitamin D and calcium content, insufficient sunlight exposure and higher numbers of birth. Gluten sensitive enteropathy is one of the most common causes of malabsorption. Gluten sensitive enteropathy is classically manifested with diarrhea, flatulence, weight loss and malabsorption. However, it can also present with non-gastrointestinal symptoms and signs, as it can be recognized by non-specific gastrointestinal symptoms. We presented a case that referred with gait abnormality and hip pain due to osteomalacia and was diagnosed as glutensensitive enteropathy.
\end{abstract}

Keywords: Osteomalacia, gluten-sensitive enteropathy, gait abnormality

\section{Özet}

Osteomalazi, D vitamini aktivitesindeki yetersizlik sonucu kemik mineralizasyonunun bozulması ile ortaya çıkan metabolik bir kemik hastalığıdır. Malabsorbsiyon durumları, vitamin D ve kalsiyumdan fakir diyetle beslenme, güneş ışı̆̆ına yetersiz maruziyet ve doğum sayısının fazla olması vitamin D eksikliğinin başlıca nedenlerindendir. Gluten enteropatisi malabsorbsiyonun sık sebeplerinden birisidir.Gluten enteropatisi klasik olarak diyare, şişkinlik, kilo kaybı ve malasorbsiyon ile karşımıza çıkar. Bununla birlikte nonspesifik gastrointestinal semptomlarla da karşımıza çıkabileceği gibi nongastrointestinal semptom ve bulgularlada karşımıza çıkar. Biz burada osteomalaziye bağlı yürüme bozukluğu ve kalça ağrısı ile gelen ve Gluten enteropatisi tanısı alan olguyu sunduk.

Anahtar sözcükler: Osteomalazi, gluten enteropatisi, yürüme güçlüğü

Geliş tarihi/Received: January 03, 2012; Kabul tarihi/Accepted: January 10, 2012

\section{*Corresponding author:}

Dr. Sevil Ceyhan Doğan, Fiziksel Tıp ve Rehabilitasyon Anabilim Dalı, Cumhuriyet Üniversitesi Tıp Fakültesi, TR-58140 Sivas. E-posta: drsevilceyhan@gmail.com

\section{Introduction}

Osteomalacia (OM) is a metabolic bone disease that occurs due to impaired bone mineralization caused byinsufficient activity of vitamin $\mathrm{D}$ (due to either vitamin $\mathrm{D}$ deficiency or resistance to vitamin D). Major clinical characteristics include bone pain and tenderness, skeletal deformity and muscle weakness; however, tetanus may rarely be seen due to hypocalcaemia. Radiologic signs include pseudo-fractures, termed as Looser line, which are particularly seen in ribs, pelvis and proximal femur. In laboratory evaluations, decreased $25(\mathrm{OH})$ vitamin D3 level, normal or decreased serum calcium (C) 
and phosphorus (P) levels, increased or normal alkaline phosphatase (ALP) level and increased parathyroid hormone level are seen. Despite this classical presentation, it may also present with several clinical findings related to musculoskeletal system [1]. Glutensensitive enteropathy (non-tropical sprue) is an auto-immune disease of intestinal mucosa, which is frequently seen among individuals with hyper-sensitivity to gluten. It may be seen in all ages; however, it is more prevalent at early adulthood. It frequently presents with symptoms such as abdominal pain, diarrhea, weight loss and loss of appetite, but there may be diverse clinical presentations, despite they are rare [2]. In the present study we presented a case who had gait abnormality and hip pain, which was diagnosed as gluten sensitive enteropathy.

\section{Case report}

A 25 years-old female presented to our outpatient clinic with pain at hip and thigh and difficulty in walking. She was suffering a difficulty in walking with increasing severity, which began 7 months ago and was severely escalated during the last 3 months. The patient who was previously able to walk independently mentioned that she was unable to walk without assistance at the time of presentation due to severe pain and weakness at lower limbs. She reported that her pain increases by standing and particularly by walking, while it relieves by rest. She had no joint pain, morning stiffness and night pain. There was no trauma, recent infection or fever and alcohol consumption/smoking or drug use in her past medical history. She needed assistance to sit and to stand up. There was a waddling gait in patient who was unable to walk without assistance. On the neuromuscular examination, localized pain was present at shoulder, forearm, hip and tibia during palpation. No pathological finding was detected in the examination of lumbar spine and knee. In hips, range of motion was limited and painful. Patient was re-examined after a resting period of 10 minutes. Passive range of motion was full, but painful at hips. In the manual muscle test, muscle weakness (Grade 2/5), particularly prominent at proximal, was detected in lower limbs. Deep tendon reflexes were normal and there was no sensorial deficit. As an initial diagnosis, we considered myopathy, inflammatory joint diseases, septic arthritis, OM, osteonecrosis and malignancy which all can cause proximal muscle weakness and pain at thigh and hip. Laboratory tests, X-ray evaluation and electromyography were ordered to exclude the diseases in differential diagnosis. In the laboratory analysis, the followings were found to be normal: complete blood count, erythrocyte sedimentation rate, liver function tests, C-reactive protein, rheumatoid factor, Brucella agglutination tests, tumor markers, serum proteins and protein electrophoresis. Pelvis, femur and hip X-rays were normal. On the EMG, motor neuron conduction velocity and distal sensorial latencies were in normal range. There was no finding that favors myopathic or neurogenic involvement. In biochemical analysis, following results were found: serum calcium: $10.2 \mathrm{mg} / \mathrm{dL}(\mathrm{N}: 8.8-10.6 \mathrm{mg} / \mathrm{dL})$; inorganic phosphorus, 4.2 $\mathrm{mg} / \mathrm{dL}(\mathrm{N}: 2.5-4.5 \mathrm{mg} / \mathrm{dL}$ ), alkaline phosphatase: $136 \mathrm{U} / \mathrm{L}$ (N: 30-120 U/L), GGT: 13 U/L (N: 0-38). Parathyroid hormone was measured in the patient with increased alkaline phosphatase and normal GGT. Since parathyroid hormone level was found as 416.9 $\mathrm{pg} / \mathrm{mL}(\mathrm{N}: 15-88 \mathrm{pg} / \mathrm{mL}$ ), it was considered that $\mathrm{OM}$ or hyperparathyroidism might be present. Thus, vitamin D levels and sonography were ordered. Sonography was interpreted as normal. However, vitamin D level was found to be quite low [25 (OH) vit D3: $2 \mathrm{ng} / \mathrm{mol}(\mathrm{N}: 10-80 \mathrm{ng} / \mathrm{mol})$ ]; so history of patient was re-assessed by interviewing with her family. Her family reported that they took her to hospital for several times until the age of 2-3 years because of vomiting, mild diarrhea and loss of appetite, but no diagnosis had been achieved; however there was a relief in her her complaints after age of 3 years. This history prompted us to order anti-gliadin antibody, where followings results were obtained: anti-gliadin IgA $24.2 \mathrm{U} / \mathrm{mL}$ (N: 0-12) and IgG $57.2 \mathrm{U} / \mathrm{mL}(\mathrm{N}: 0-12)$. An esophagogastroduodenoscopy was performed and endoscopic duodenal biopsy samples were taken. Result of intestinal biopsy was compatible with gluten sensitive enteropathy. Results of DEXA evaluation (Dual-energy X-ray absorptiometry) was in agreement with osteoporosis (L1-4 T score: -3.9 and femur neck T score: -3.0$)$. 
A dietary arrangement was made for gluten sensitive enteropathy. We prescribed 300.000 IU per week vitamin D (IM) for first month; followed by 300.000 IU vitamin D injections (IM) at every 3 weeks. She was also prescribed $1000 \mathrm{mg} /$ day elemental calcium (PO). On the control visit at month 6 , it was found that walking, muscle weakness and abnormal laboratory results returned to normal.

\section{Discussion}

Sometimes, gluten sensitive enteropathy has a course including mild symptoms and signs. OM cases with atypical clinical presentation and resistance to treatment should be evaluated for gluten sensitive enteropathy [3]. Initially, we didn't consider gluten enteropathy in this case which had normal development and no gastrointestinal complaint. Mühlebach et al. [5] reported severe vitamin D deficiency might be associated to musculoskeletal pain and fatigue by presenting a 32-years old woman who had pain at neck, back and thigh as well as weakness particularly at pelvic girdle. In a study, Karadavut et al. [3] found that there was fatigue and weakness in all patients with severe vitamin D deficiency, while altered gait and musculoskeletal pain in majority of the patients. In our case, there was weakness and fatigue. Again, osteomalacic myopathy was investigated in a study conducted at 3 facilities in Saudi Arabia. In that study, it was emphasized that vitamin D deficiency should be screened in patients with acquired myopathy to identify a curable cause of the situation [6]. Correspondingly, there was proximal muscle weakness and difficulty in walking in our patient and we ordered muscle enzymes and EMG with the consideration of myopathy but results were completely normal. However, we suspected from OM as PTH level was quite high. While evaluations were being performed in order to reveal etiology of OM, we found out that the patient had gluten sensitive enteropathy. Occasionally, gluten sensitive enteropathy may manifest with atypical, extra-intestinal findings. Thus, diagnosis can be made by evaluations and good anamnesis in some cases. Among the patients with OM, myopathy incidence was reported as $73 \%$ in one study, whereas $97 \%$ in another. Therefore, OM should be kept in mind in patients with muscle weakness [7]. Osteopenia, osteomalacia or osteoporosis commonly exist in patients with gluten sensitive enteropathy. Valdimarsson et al. [8] evaluated the effect of gluten-free diet on bone mineral density in a 63-years old man. Patient was assessed at the time of diagnosis and 1 year after gluten-free diet. Authors found that bone mineral density rapidly increased with gluten-free diet in patients with untreated gluten sensitive enteropathy. In a study by Mora $S$ et al. [9], it was demonstrated that normal bone turnover and mineralization could be achieved by longterm gluten-free diet. We also scheduled gluten-free diet and prescribed vitamin D and calcium supplementation in our patient who had osteoporosis.

We detected gluten sensitive enteropathy in a patient who was initially considered as myopathy and underwent evaluation. This should warn us to evaluate the patients that present with difficulty in walking for $\mathrm{OM}$ and gluten sensitive enteropathy [10]. In conclusion, gluten sensitive enteropathy should be kept in mind in patients diagnosed as $\mathrm{OM}$ and resistant to oral vitamin $\mathrm{D}$ supplementation. Better understanding of associations among these diseases and findings is essential for accurate diagnosis in a patient who presents with difficulty in walking.

\section{References}

1. Stamp TCB. Ricets and Osteomalacia. In Klippel JH, Dieppe PA (eds.). Rheumatology Second Edition. London: Mosby International 1998: 8; 1-12.

2. Aydın NA, Yazıcıoğlu K. Kemik Ağrısı ile Seyreden Çölyak Hastalığı: İki Olgu Sunumu. Türk Osteoporoz Dergisi 2011; 17: 24-5.

3. Karadavut Kİ, Başaran A, Çakcı A. Türk Kadınlarında Vitamin D Eksikliği. Osteoporoz Dünyasindan 2003; 9: 74-9.

4. Kondolot M. Demirçeken F, Ertan Ü. 52 Vaka İle Türk Çocuklarında Çölyak Hastalığı. Türkiye Çocuk Hast Derg 2009; 31: 10-7. 
5. Mühlebach S, Bischoff-Ferrari HA. Myalgia and proximal muscle weakness in a young patient. Praxis (Bern 1994) 2009; 98: 447-50.

6. Al-Said YA, Al-Rached HS, Al-Qahtani HA, Jan MM. Severe proximal myopathy with remarkable recovery after vitamin D treatment. Can J Neurol Sci 2009; 36: 336-9.

7. Tezyürek M, Aksel J, Karaoğlan B. Hipofosfatemik Osteomalazi: Bir Olgu Sunumu. Fiziksel Tip 2002; 5: 113-6.

8. Valdimarsson T, Löfman O, Toss G, Ström M. Reversal of osteopenia with diet in adult coeliac disease. Gut 1996; 38: 322-7.

9. Mora S, Barera G, Beccio S, Proverbio MC, Weber G, Bianchi C, Chiumello G. Bone density and bone metabolism are normal after long-term gluten-free diet in young celiac patients. Am J Gastroenterol 1999; 94: 398-403.

10. Başaran A, Karadavut Kİ, Aydoğ E, Çakc1 A. Serological Diagnosis of Subclinical Gluten Enteropathy: A Case Presented As Treatment Resistant Osteomalacia. Turkish Journal of Rheumatology 2006; 21: 118-20. 